\title{
Noninvasive Markers of Improvement of Liver Steatosis Achieved by Weight Reduction in Patients with Nonalcoholic Fatty Liver Disease
}

\author{
I. COPACI ${ }^{1}$, IOANA LUPESCU ${ }^{1}$, ELENA CACEAUNE ${ }^{2}$, GRETHI CHIRIAC ${ }^{1}$, G. ISMAIL ${ }^{1}$ \\ ${ }^{1}$ Fundeni Clinical Institute, Center of Internal Medicine \\ 2“Prof. Dr. N. Paulescu” National Institute for Diabetes, Nutrition and Metabolic Diseases, Bucharest, Romania
}

\begin{abstract}
Nonalcoholic fatty liver disease (NAFLD) is strongly associated with insulin resistance and metabolic syndrome, which are linked to obesity. The aim of the study was to assess if weight reduction through 12 months of lifestyle intervention and exercise would lead to improvement of steatosis.

Methods. In a prospective observational study 86 overweight subjects (51 men, 35 women) with steatosis were recruited, after excluding other etiologies. Patients were assigned a caloric goal and a daily fat goal. Physical activity focused on moderate-intensity activities. Blood samples (biochemistry, HOMA-IR, cytokine levels, steatotest) were collected at entry and months 6 and 12 . All subjects underwent abdominal CT scan before commencement and after 12 months to assess visceral and subcutaneous adipose tissue (VAT/SAT) area.

Results. After 12 months baseline descriptive characteristics (weight, BMI, waist circumference) decreased significantly. Biochemical parameters that decreased significantly were: GGT $(40.0 \pm 18.0$ vs $31.1 \pm 13 ; \mathrm{p}=0.01)$, ALT $(58.5 \pm 23.5$ vs $32,7 \pm 14.8 ; \mathrm{p}=0.001)$, cholesterol $(236.4 \pm 54.8 v s$ $204.8 \pm 91 ; \mathrm{p}=0.05)$, LDL $(160.1 \pm 47.4$ vs $125.3 \pm 40 ; \mathrm{p}=0.05)$ and HOMA-R $(4.86 \pm 0.63$ vs $3 \pm$ $0.41 ; \mathrm{p}=0.018)$. Steatotest improved significantly $(0.68 \pm 0.16$ vs $0.38 \pm 0.14 ; \mathrm{p}=0.02)$. Modification of adipocytokines was significant for leptin $(p=0.018)$ and adiponectin $(p=0.003)$. Factors associated with regression of steatosis were weight, BMI, ALT, waist circumference, GGT, HOMA, leptin, VAT and steatotest. Multivariate logistic regression showed the following factors related to improved steatosis: $\mathrm{BMI}<25 \mathrm{~kg} / \mathrm{m}^{2}, \mathrm{ALT}<42 \mathrm{U} / \mathrm{L}$, leptin $<10.5 \mathrm{ng} / \mathrm{ml}$ and adiponectin $>$ $8.4 \mu \mathrm{g} / \mathrm{ml}$.

Conclusions. Overweight persons who achieve significant reductions in body weight through 12 months of physical activity and low caloric diet can decrease liver fat, VAT and SAT. Even in those with minimal weight loss ALT levels, steatosis, adipokines and cardiovascular risk factors improved.
\end{abstract}

Key words: non-alcoholic fatty liver disease, weight reduction, steatosis.

NAFLD has been shown to be closely linked to insulin resistance and the metabolic syndrome, and there is a clear association between the current high prevalence of the metabolic syndrome and obesity [1-4]. Studies have shown that, although obesity reflects an increase in adipose tissue mass and is associated with insulin resistance [5], development of the metabolic syndrome is also influenced by the distribution of adipose tissue in the body $[1,6,7]$. Adipose tissue is regarded as an active organ in regulating metabolism by releasing adipokines that contribute to peripheral insulin resistance [8]. Body fat distribution is important for metabolic consequences, the visceral component being a significant predictor of diabetes $[9,10]$. There is currently increasing evidence that distribution of fat in other areas also influences the metabolic risks associated with obesity $[1,11]$.
There is evidence supporting the link between NAFLD and increased morbidity and mortality due to cardiovascular disease, regardless of risk factors that compose the metabolic syndrome [12-14]. Epidemiological studies report a lower prevalence of metabolic syndrome in individuals with higher participation in physical activity (PA), higher muscle strength, and higher cardiorespiratory fitness (CRF) [15]. Because pharmaceutical and non-pharmaceutical agents have not proven absolute efficacy and because NAFLD is often associated with obesity, diet modification and physical activity have been shown to attenuate metabolic syndrome and decrease cardiovascular mortality [16]. Church et al. were the first to suggest a similar inverse relationship between $\mathrm{CRF}$ and the prevalence of NAFLD [17], and Perseghin et al. [18] demonstrated an inverse relationship between habitual PA 
and intrahepatic fat content. Nowadays, the discussions about the benefits of PA per se versus diet on the evolution of NAFLD are contradictory [19]. Some of the studies have shown that PA is in a reverse relation with intrahepatic fat and peripheral transaminases levels [20]. These data are crucial, as most therapeutic guidelines for persons with NAFLD suggest weight loss through lifestyle changes that include diet modifications and exercise participation [21]. However, assessment of CRF is not addressed, and precise recommendations for exercise do not exist.

The aim of the study was to assess if weight reduction obtained through 12 months of intensive lifestyle intervention and exercise regimens would lead to improvement of liver steatosis.

\section{MATERIALS AND METHODS}

In a prospective study performed between January 2010 - January 2013 in the Center of Internal Medicine of Fundeni Clinical Institute, 86 subjects (51 men and 35 women) with a BMI between 25 and $40 \mathrm{~kg} / \mathrm{m}^{2}$ and liver steatosis (steatotest, echo and CT) were recruited, after excluding individuals with any of the following: alcohol consumption $\geq 30 \mathrm{~g} /$ day in men or $20 \mathrm{~g} /$ day in women, presence of HBsAg or anti-HCV antibodies, fatty liver suspected to be secondary to hepatotoxic drugs, inflammatory bowel disease, celiac disease, autoimmune disease, jejunal-ileal by-pass.

Other major exclusion criteria were: inability to walk 2 blocks or 500 meters without stopping, pregnancy, intake of weight-loss medication and psychiatric problems.

All patients were assigned a caloric goal based on their starting weight $(1000-1200 \mathrm{kcal} /$ day if baseline weight was more than $100 \mathrm{~kg}$ or 1200 $1500 \mathrm{kcal} /$ day if baseline weight was lower than $100 \mathrm{~kg}$ ) and a daily fat gram goal designed to produce a $25 \%$ fat diet (28-33 gr for $1000-1200$ kcal diet or 33-42 gr for the 1200-1500 kcal diet).

During the program, participants were given meal plans that provided different options for meals and snacks. The use of a portion-controlled food promotes dietary adherence. Dietary compliance was assessed by using urinary ketone reagent strips (Keto-Diastix; Bayer Diagnostics). The presence of at least traces of ketones in the urine was considered to indicate net lipolysis and dietary adherence, and the test was performed each month.

The program of physical activity focused on moderate-intensity activities, with particular emphasis on walking. Other activities such as bicycling, aerobic exercises and strength were also encouraged. Participants were instructed to gradually progress to a goal of $200 \mathrm{~min} /$ week of moderate-intensity physical activity (achieving this goal by the end of the first 6 months). Blood was obtained in the fasting state at entry and months 6 and 12 and was tested for alanine aminotransferase, aspartate aminotransferase, gamma glutamyltransferase, alkaline phosphatase, bilirubin, albumin, total cholesterol, triglycerides, high-density lipoprotein, low-density lipoprotein, HOMA-IR (homeostatis model assessment), a surrogate measurement of insulin resistance as well cytokine levels (leptin, adipokine) and steatotest (Biopredictive, Paris). Liver biopsy was only accepted by 10 patients.

All participants were seen by the study principal investigator every 12 weeks and had a standard care of their liver disease. Participants were also seen weekly by a nutritionist for the first 6 months and then every two weeks from months 7 through 12.

All participants provided written informed consent prior to enrollment, and the study was approved by the Ethical Committee of Fundeni Clinical Institute.

\section{COMPUTED TOMOGRAPHY MEASUREMENTS}

All subjects underwent an abdominal CT scan before commencement and at completion of 12 months. All investigations were performed in a supine position during a single breath hold while the arms were extended over head. Contiguous 8$\mathrm{mm}$ slices were then taken, including at least one image superior to and one inferior to the liver, to ensure that the entire organ was captured. The scan was performed by using a spiral sequence without medium contrast $(\mathrm{kV}=120, \mathrm{~mA}=250$, gantry rotation $=0.75$ revolutions, table speed $=48 \mathrm{~mm} / \mathrm{s}$, effective pitch $=4.5$, matrix $=512 \times 512$, and field of view $=500 \mathrm{~mm}$ ).

Changes in visceral and subcutaneous adipose tissue (VAT/SAT) area were determined through comparison of a single transaxial image at the level of the intervertebral space between the second and third lumbar vertebrae. These images were taken while the liver scan was performed at baseline and month 12 .

The grading of hepatic steatosis was done based on hepatic-splenic attenuation difference on enhanced CT: $>5 \mathrm{HU}$ : absence of significant steatosis $(0-5 \%) ;-10$ to $5 \mathrm{HU}$ : mild to moderate steatosis $(6-30 \%),<-10 \mathrm{HU}$ : moderate to severe steatosis $(>30 \%)$. 


\section{STATISTICAL ANALYSIS}

Data are presented as the mean $\pm \mathrm{SD}$ if normally distributed and median $(25,75$ percentile) in the case of non-gaussian distribution. Differences between groups were tested using two-tailed Student's t test or Mann Whitney $U$ test as appropriate for two-group comparisons or using ANOVA for multiple group comparisons. Categorical variables were compared with the $\chi 2$-test. All p-values are two tailed, with $\mathrm{p}<0.05$ considered statistically significant.

Receiver operator characteristic (ROC) curve analysis was performed to identify cut-off values for parameters significantly correlated with the improvement of liver steatosis.

Variables included in the multivariate analysis were selected on the basis of the best results of univariate analyses (at a significance level of $p<$ 0.05). Logistic regression of predictive factors used reduction of liver steatosis as dependent variable and gender, weight, BMI, ALT, GGT, HOMA, glucose, VAT, leptin and adiponectin as independent predictive variables in a single model. Results were expressed as odds ratios $(\operatorname{Exp} \beta)$ with 95\% CIs.

Statistical analysis was performed using SPSS for Windows version 17.0 (SPSS, Inc., Chicago, IL).

\section{RESULTS}

86 subjects were recruited into the study and commenced the 12-month protocol. The group consisted of 51 men and 35 women and their mean $( \pm \mathrm{SD})$ age was $47.7 \pm 12.8$ years. Descriptive characteristics are presented in Table 1. Body weight ranged from 80 to $126 \mathrm{~kg}$ and BMI from $25.2 \mathrm{~kg} / \mathrm{m}^{2}$ to $42.3 \mathrm{~kg} / \mathrm{m}^{2} .28 \%$ had diabetes mellitus type II, 54.6\% had hypertension and $30.2 \%$ had hypercholesterolemia (Table I).

At completion of 12 months of protocol all baseline descriptive characteristics for the 86 subjects decreased significantly: body weight, BMI, waist circumference (Table II). Baseline biochemical variables are shown in Table III. After 12 months the parameters that decreased were: GGT $(40.0 \pm$ 18 vs. $31.1 \pm 13, \mathrm{p}=0.01)$, ALT $(58.5 \pm 23.5 v s$. $32.7 \pm 14.8, p=0.001)$, cholesterol $(p=0.05)$, LDL $(\mathrm{p}=0.05)$ and HOMA-R $(4.86 \pm 0.63$ vs. $3 \pm$ $0.41, \mathrm{p}=0.018)$. Steatotest decreased from $0.68 \pm$ 0.16 at baseline to $0.38 \pm 0.14(p=0.02)$, after 12 months reflecting the reduction of fat accumulation in the liver. CT assessment showed a mean VAT deposition of $131 \pm 52 \mathrm{~cm}^{2}$ (range 86.9$202 \mathrm{~cm}^{2}$ ) and a mean SAT of $307 \pm 75 \mathrm{~cm}^{2}$ (range 201-586 $\mathrm{cm}^{2}$ ). After 12 months SAT decreased more pronouncedly than VAT (Table II).

The modification of adipocytokines was significant for leptin $(7.8 \pm 3.1$ vs. $15.3 \pm 4.8, \mathrm{p}=$ $0.018)$ and adiponectin $(9.9 \pm 3.8 v s .8 .1 \pm 3.3, \mathrm{p}=$ 0.003 ) at the end of the study (Table II). Improvement of liver steatosis, assessed by hepaticsplenic attenuation difference was significant regardless of the initial steatosis intensity (Table 3). Factors associated with reduction of liver steatosis were weight, BMI, ALT, waist circumference, GGT, HOMA, leptin, VAT and steatotest (Table IV).

Median values of BMI, ALT, leptin and adiponectin were chosen as cut-off values in the multivariate analysis.

Multivariate logistic regression analysis of factors related to improved liver steatosis showed: BMI $<25 \mathrm{~kg} / \mathrm{m}^{2}(\mathrm{OR}=4.23$ [1.63-10.95, $\mathrm{p}=$ $0.02]), \operatorname{ALT}(<42 \mathrm{U} / \mathrm{L})(\mathrm{OR}=2.4[1.9-3.2, \mathrm{p}=$ $0.017])$, leptin $(<10.5 \mathrm{ng} / \mathrm{ml}, \mathrm{p}=0.06)(\mathrm{OR}=2.7$ $[1.5-4.9, \mathrm{p}=0.017])$, and adiponectin $(>8.4 \mu \mathrm{g} / \mathrm{ml})$ $(\mathrm{OR}=2.45$ [1.23-4.48], $\mathrm{p}=0.010)($ Table V).

Table I

Descriptive analysis of study participants

\begin{tabular}{|l|c|c|c|}
\hline \multicolumn{1}{|c|}{ Anthropometric indices } & Overall $(\mathbf{n}=\mathbf{8 6})$ & Male $(\mathbf{n}=\mathbf{5 1})$ & Female (n = 35) \\
\hline Age $(\mathrm{yr})$ & $47.7 \pm 12.8$ & $49.6 \pm 10.3$ & $43.5 \pm 11.2$ \\
\hline Height $(\mathrm{cm})$ & $166.4 \pm 12.1$ & $175.9 \pm 19.3^{*}$ & $161.9 \pm 10$ \\
\hline Weight $(\mathrm{kg})$ & $100.8 \pm 14.2$ & $106.8 \pm 25^{*}$ & $90.6 \pm 17$ \\
\hline BMI $\left(\mathrm{kg} / \mathrm{cm}^{2}\right)$ & $33.8 \pm 6.02$ & $34.6 \pm 7.1$ & $32.3 \pm 5.2$ \\
\hline Waist circumference (cm) & $101.3 \pm 15.2$ & $103.4 \pm 17.8$ & $98 \pm 20.3$ \\
\hline Waist/hip ratio & $0.85 \pm 0.23$ & $0.90 \pm 0.21$ & $0.82 \pm 0.21$ \\
\hline Triceps skinfold (mm) & $25.8 \pm 10.3$ & $25.4 \pm 8.1$ & $26.5 \pm 11.3$ \\
\hline Biceps skinfold (mm) & $21.2 \pm 10.2$ & $19.6 \pm 7.2$ & $22.3 \pm 11.2$ \\
\hline $\begin{array}{l}\text { Disease status } \\
\text { Diabetes mellitus II }\end{array}$ & $24 / 86(28 \%)$ & $10(19.6 \%)$ & $14(40 \%)$ \\
\hline Hypertension & $47 / 86(54.6 \%)$ & $21(41.1 \%)$ & $26(74.2 \%)$ \\
\hline Hypercholesterolemia & $26 / 86(30.2 \%)$ & $12(23.5 \%)$ & $14(40 \%)$ \\
\hline $\begin{array}{l}\text { Data are presented as mean and standard deviation. BMI - body mass index, } *=p<0.05 \text { when compared to the other } \\
\text { sex group. }\end{array}$
\end{tabular}


Table II

Descriptive characteristics of subjects before and after 48 weeks

\begin{tabular}{|c|c|c|c|}
\hline Variable & Baseline & After 48 wk & $P$ - Value \\
\hline Weight (kg) & $100.8 \pm 14.2$ & $91.2 \pm 10.1$ & 0.004 \\
\hline BMI $\left(\mathrm{kg} / \mathrm{cm}^{2}\right)$ & $33.8 \pm 6.02$ & $26.1 \pm 4.0$ & 0.0017 \\
\hline Waist circumference $(\mathrm{cm})$ & $101.3 \pm 15.2$ & $90.6 \pm 8.9$ & 0.003 \\
\hline Waist/hip ratio & $0.85 \pm 0.23$ & $0.81 \pm 0.22$ & 0.002 \\
\hline $\operatorname{SAT}\left(\mathrm{cm}^{2}\right)$ & $307 \pm 75$ & $254 \pm 103$ & 0.017 \\
\hline $\operatorname{VAT}\left(\mathrm{cm}^{2}\right)$ & $131 \pm 52$ & $109 \pm 42$ & 0.010 \\
\hline Leptin (ng/mL) & $15.3 \pm 4.8$ & $7.8 \pm 3.1$ & 0.018 \\
\hline Adiponectin (microg/mL) & $8.1 \pm 3.3$ & $9.9 \pm 3.8$ & 0.003 \\
\hline GGT (U/L) & $40.0 \pm 18.0$ & $31.1 \pm 13$ & 0.01 \\
\hline $\operatorname{ALT}(\mathrm{U} / \mathrm{L})$ & $58.5 \pm 23.5$ & $32.7 \pm 14.8$ & 0.001 \\
\hline $\operatorname{AST}(\mathrm{U} / \mathrm{L})$ & $30.4 \pm 12.7$ & $20.8 \pm 11.3$ & NS \\
\hline Cholesterol (mg/dl) & $236.4 \pm 54.8$ & $204.8 \pm 91$ & 0.05 \\
\hline LDL (mg/dl) & $160.1 \pm 47.4$ & $125.3 \pm 40$ & 0.05 \\
\hline HDL (mg/dl) & $38.1 \pm 9.6$ & $42.2 \pm 10.3$ & NS \\
\hline Triglycerides $(\mathrm{mg} / \mathrm{dl})$ & $211 \pm 58.6$ & $160.3 \pm 47$ & NS \\
\hline Glucose $(\mathrm{mg} / \mathrm{dl})$ & $122.0 \pm 27.2$ & $113.7 \pm 22.6$ & NS \\
\hline HbA1c (\%) & $6.3 \pm 1.0$ & $4.8 \pm 0.7$ & NS \\
\hline HOMA & $4.86 \pm 0.63$ & $3 \pm 0.41$ & 0.018 \\
\hline Steatotest & $0.68 \pm 0.16$ & $0.38 \pm 0.14$ & 0.02 \\
\hline \multicolumn{4}{|c|}{$\begin{array}{l}\text { Data are presented as mean and standard deviation. BMI - body mass index; SAT - subcutaneous adipose tissue; } \\
\text { VAT - visceral adipose tissue; HOMA - homeostatis model assessment; BMI - body mass index; ALT - alanine } \\
\text { aminotransferase; AST - aspartate aminostransferase; GGT - gamma-glutamyltranspeptidase; HDL - high-density } \\
\text { lipoprotein; LDL - low-density lipoprotein; HbA1c - glycated hemoglobin. }\end{array}$} \\
\hline
\end{tabular}

Table III

Evaluation of CT steatosis after weight loss

\begin{tabular}{|l|c|c|}
\hline \multicolumn{1}{|c|}{ CT steatosis } & \multicolumn{1}{|c|}{$\begin{array}{c}\text { Baseline } \\
\text { (no. pts) }\end{array}$} & $\begin{array}{c}\text { After 48 weeks } \\
\text { (no. pts) }\end{array}$ \\
\hline Absence of significant steatosis ( $\geq 5 \mathrm{HU})$ & 0 & 38 \\
\hline Mild to moderate steatosis (-10 to 5 HU) & 50 & 41 \\
\hline Moderate to severe steatosis $(<-10 \mathrm{HU})$ & 36 & 7 \\
\hline HU - Houndsfield unit & & \\
\hline
\end{tabular}

Table IV

Univariate analysis: factors associated with regression of liver steatosis

\begin{tabular}{|l|c|c|c|c|}
\hline & p value & OR & \multicolumn{2}{c|}{ 95.0\% CI for OR } \\
\cline { 3 - 5 } & & & Lower & Upper \\
\hline BMI & 0.020 & 4.23 & 1.63 & 1.9 \\
\hline ALT(U/L) & 0.027 & 2.4 & 1.5 & 4.2 \\
\hline Leptin $(\mathrm{ng} / \mathrm{ml})$ & 0.017 & 2.7 & 1.23 & 4.48 \\
\hline Adiponectin $(\mu \mathrm{g} / \mathrm{ml})$ & 0.010 & 2.45 & 4.95 \\
\hline
\end{tabular}

Table $V$

Multivariate analysis: factors associated with regression of liver steatosis

\begin{tabular}{|l|c|c|c|}
\hline \multicolumn{1}{|c|}{ Variable } & $\begin{array}{c}\text { Pts. without regression } \\
\text { of liver steatosis }\end{array}$ & $\begin{array}{c}\text { Pts. with regression } \\
\text { of liver steatosis }\end{array}$ & $P$ - Value \\
\hline Weight $(\mathrm{kg})$ & $103.9 \pm 13.1$ & $97.8 \pm 13.4$ & 0.002 \\
\hline BMI $\left(\mathrm{kg} / \mathrm{m}^{2}\right)$ & $33.7 \pm 4.7$ & $28.7 \pm 6.2$ & 0.010 \\
\hline Waist circumference $(\mathrm{cm})$ & $108.1 \pm 5.6$ & $91.3 \pm 4.7$ & 0.024 \\
\hline ALT $(\mathrm{U} / \mathrm{L})$ & $85.5 \pm 36.5$ & $61 \pm 24.3$ & 0.018 \\
\hline GGT (U/L) & $49.8 \pm 23.3$ & $32 \pm 13$ & 0.034 \\
\hline HOMA & $4.36 \pm 2.4$ & $3.1 \pm 0.9$ & 0.028 \\
\hline Leptin $(\mathrm{ng} / \mathrm{ml})$ & $20.4 \pm 8.1$ & $9.8 \pm 4.1$ & 0.003 \\
\hline VAT $\left(\mathrm{cm}^{2}\right)$ & $160.1 \pm 38$ & $118 \pm 42$ & 0.017 \\
\hline Steatotest & $0.45 \pm 0.18$ & $0.32 \pm 0.15$ & 0.034 \\
\hline Adiponectin $(\mu \mathrm{g} / \mathrm{ml})$ & $5.72 \pm 3.43$ & $8.4 \pm 2.07$ & 0.002 \\
\hline \multicolumn{2}{|l|}{$\begin{array}{l}\text { Data are presented as mean and standard deviation. VAT - visceral adipose tissue; HOMA - homeostatis model } \\
\text { assessment; ALT - alanine aminotransferase; BMI - body mass index; GGT - gamma-glutamyltranspeptidase; HU - } \\
\text { houndsfield unit }\end{array}$} \\
\hline
\end{tabular}




\section{DISCUSSION}

Our study presents importance due to the number of patients who adhered to this double change of life-style, due to the imagistical quantification of VAT/SAT and due to measurement of adipokines, all of which demonstrate the benefits that can be achieved without drug intervention.

Physical activity (PA) is considered to be essential for a healthy lifestyle. Although it is now a proven fact that PA has a protective role in cardiovascular and metabolic diseases, its importance in NAFLD still requires scientific evidence $[22,23]$. In our present research we studied the influence of nutrition and PA on NAFLD. Regular weekly PA was associated with a lower grade of hepatic steatosis. This was associated with lower BMI, abdominal obesity, serum cholesterol, ALT, GGT and HOMA-IR. These results are consistent with other studies that have shown that PA correlates with indirect markers of NAFLD, respectively transaminase and $\gamma$-glutamyltransferase [24] or NAFLD prevalence [25].

We compared our study with a meta-analysis of 12 other studies in the literature that assessed the efficacy of exercise in modulating hepatic steatosis [26]. Seven studies used interventions of aerobic exercise, two studies have used progressive resistance training and other 3 studies the combination of the two techniques above. In some studies, weight loss was modest (1.4 -2.2 kg), but the study period was short (4-10 weeks). All studies have shown that exercise interventions lead to a decrease of intrahepatic fat despite a minimum weight loss [26].

Univariate analysis showed that weight, BMI and waist circumference, as well as some biological parameters (leptin and adiponectin), have the highest statistical significance in determining the risk of not responding to life-style changes, and these patients could be considered for bariatric surgery.

Regular exercise in laboratory animals reduces hepatic steatosis by decreasing the activity of lipogenic enzymes acetyl-coenzyme A carboxylase and fatty acid synthase and by reducing the activity of mitochondrial enzymes of fatty acid oxidation [27].

As expected, steatosis and visceral adiposity were significantly correlated with severe steatosis (grade 3), being much more prevalent in patients with the largest waist circumference. The prevalence of NASH increased with increasing waist circumference, being $55 \%$ and $72 \%$ in lean and obese subjects [28]. Recently it has been proposed that a surge of insulin resistance in the adipose tissue leads to excess free fatty acids in the periphery, with ectopic accumulation and activation of nonoxidative metabolic pathways and with accumulation of toxic products that activate inflammatory pathways (IKB/NF-kB; jun N-terminal kinase). For example, pericardial adipose tissue is more closely associated with coronary artery disease than waist circumference [29].

In patients with NAFLD, it is recommended to obtain weight loss and an improvement in blood glucose level, dyslipidemia and in cardiovascular risk through diet with or without physical activity. In our study we used an energy-restricted diet $(1000-1500 \mathrm{kcal} /$ day $)$ with a certain structure, based on recommendations from the literature. Considering that saturated fat causes endoplasmatic reticulum stress, these were limited in the diet, but not less than $10 \%$ since it has been shown that a drop below 7\% generates triacylglycerol increases after 6 weeks, and decreases in HDL [30]. Also, the diet contained polyunsaturated fatty acids, knowing that they decrease the risk of coronary heart disease and change the lipid composition of the hepatocyte membrane [31].

Low-carbohydrate diets with fructose restriction and low fat diets reduce aminotransferase levels and intrahepatic fat [32].

Several studies have shown that weight loss achieved by diet reduces liver enzymes and fatty liver, but has less significant effects on other histological components. In such a randomized trial [33] carried out on patients with NASH, in which a group was submitted to lifestyle changes (diet, exercise) versus a control group, the NAFLD activity score after 48 weeks was assessed. In the study group, a $1000-1500 \mathrm{kcal} /$ day diet with $25 \%$ fat was used, according to body weight. Those who had a weight loss of over 7\% showed an improvement in steatosis $(\mathrm{p}<0.001)$, lobular inflammation $(\mathrm{p}<0.03)$ and the NAFLD activity score $(\mathrm{p}<$ $0.001)$.

Our study underlines the known health benefits of PA; PA and diet with a low caloric goal reduces liver steatosis in parallel with visceral and subcutaneous adipose tissue. The degree of steatosis was assessed by CT and steatotest, a biochemical surrogate of liver steatosis. For Steatotest, a cut-off value of 0.30 had a $91 \%$ sensibility and $89 \%$ specificity in differentiating grade I steatosis $(<5 \%)$ from grade II steatosis $(6-32 \%)$, while a cut-off of 0.70 differentiated grade II from grade III steatosis $(>32 \%)$. Lifestyle program modification induces decreases of intrahepatic fat content, topography index, HOMA-IR and sonographic 
aspects [34]. The association of PA with adipocytokines may explain, at least in part, the PANAFLD association. The adipocytokines leptin, adiponectin and resistin have all been incriminated in the development of hepatic steatosis, inflammation and fibrosis in patients with NAFLD. Serum leptin levels and resistin positively correlate with hepatic steatosis $[35,36]$.

It is not surprising that leptin is a mediator in the PA-NAFLD association, because leptin serum concentrations have been shown to be reduced by long-term aerobic exercise and resistance exercise $[37,38]$. Thus, exercise may improve leptin resistance, which has been shown to be associated with the pathogenesis of hepatic steatosis [39].

As plasma leptin concentrations are tightly linked to fat mass in humans, decreases in adipose mass with weight loss coincide with decreased concentrations of circulating leptin [40].

In hepatic steatosis, the macrophages are activated by leptin, and through NOS and NADPH oxidase, generate oxidative stress and produce THF $\alpha$ and MCP-1 from Kupffer cells [41].

Adiponectin inhibit lipogenesis via sterol regulatory element-binding protein 1 (this can be induced by $\mathrm{TNF} \alpha$ ) and generates endoplasmic reticulum stress [42]. Adiponectin levels are low in obese patients and in those with NAFLD. In our study, weight loss and improvement of steatosis were accompanied by significant changes of serum levels of the two adipokines (leptin $15.3 \pm 4.8$ initially declined to $7.8 \pm 3.1, \mathrm{p}=0.018$; adiponectin $8.1 \pm 3.3 v s .9 .8 \pm 3.8, \mathrm{p}=0.003$ ). Exercise training influences plasma levels of adiponectin and insulin sensitivity (HOMA).

These results are in line with the findings of Targher et al. [43] that hypoadiponectinemia closely correlated with NAFLD in obese individuals, which was only slightly weakened after adjustment for BMI and waist-to-hip ratio. We therefore believe that serum adiponectin level is the most sensitive reflection of hepatic steatosis. Waist circumference (WC) is the best anthropometric index for obesity and especially for visceral obesity. This is supported by the fact that VAT, but not SAT, is a predictor of diabetes in both genders [44].

Visceral fat is the source of free fatty acids and adipokines reaching the liver through the portal vein, explaining the metabolic abnormalities associated with abdominal obesity. Therefore, the reduction of visceral obesity is a therapeutic goal in the management of obesity. In a recent study of obese patients or overweight patients with type 2 diabetes mellitus, a 12-month intensive lifestyle intervention revealed a reduction of steatosis, assessed by magnetic resonance spectroscopy in patients with weight loss of over $10 \%$ [45].

Recently, it has become clear that VAT correlates directly with intrahepatic triglyceride (IHTG) content, and an increase in IHTG is associated with the same metabolic abnormalities linked to an increase in VAT [46, 47]. In multivariate logistic regression analysis of factors related to improved liver steatosis in our group, VAT was not significantly correlated after 12 months of lifestyle modifications. The mechanism explaining this relative reduction relates to the accumulation of fat. In early steatosis, centrolobular lipid accumulation occurs, which progressively includes the entire lobule. In severe steatosis, a significant proportion of hepatocytes can reduce their own size when the weight loss process occurs. This contrasts with changes in VAT, where adipocytes slowly and uniformly reduced their size during weight loss.

Our study measured and compared changes in liver fat, VAT and SAT over 12 months of weight loss. CT was selected because of its proven accuracy for assessing liver structure and VAT, more moderate expense and shorter acquisition time, which reduces movement artifacts and provides high accuracy and precision [48]. However, the radiation exposure for patients and the significant variation in absolute liver attenuation values obtained using different machines represent important limitations. It was not possible for us to use other imagistical investigations such as proton magnetic resonance spectroscopy or MR elastography.

Another limitation of the study is represented by the fact that the majority of patients refused liver biopsy.

Unlike other studies, we extended the dietary intervention to 12 months, to achieve an optimal balance between maximal reduction of liver fat and a reduction in VAT stores and body weight, without compromising patient compliance and acceptability.

During periods of negative energy balance, changes in fat distribution favor a reduction in visceral fat. This preferential reduction in VAT may be explained by previous observations, which suggest that visceral fat is more sensitive than SAT to lipolytic stimulation and less resistant to insulin suppression [49].

In our study patients adhered to a double change in life-style (diet and physical activity), but we could not establish which of the two interventions 
determined a more important improvement of liver disease. This approach was chosen in order to obtain a maximum benefit for our patients.

In summary, overweight persons who achieve significant reductions in body weight through 12 months of PA and low caloric diet can safely and effectively decrease liver fat, VAT and SAT. Even in those who had minimal weight loss ALT levels, liver steatosis, adipokines and cardiovascular risk factors improved. Liver fat does not appear to simply reflect the size of endogenous fat stores. Change in ALT, leptin and adiponectin achieved by weight reduction could predict improvement in liver steatosis. It is also unclear what kind of exercise would best improve hepatic insulin sensitivity and/or lead to the greatest loss of liver fat. Beyond these limitations, there appears to be a benefit from lifestyle modifications involving increased physical activity and weight loss to reverse fatty liver disease.

Ficatul gras non-alcoolic este puternic asociat cu rezistența la insulină şi cu sindromul metabolic, care sunt legate de obezitate. Scopul studiului a fost de a evalua dacă scăderea ponderală obținută prin 12 luni de intervenție asupra stilului de viață şi exerciții fizice ar conduce la ameliorarea steatozei hepatice.

Metode. Am recrutat intr-un studiu prospectiv, observațional, 86 subiecți supraponderali (51 bărbați, 35 femei) cu steatoză, după excluderea altor etiologii. Pacienților li s-a atribuit o țintă calorică şi o țintă zilnică de grăsimi. Activitatea fizică s-a bazat pe activități de intensitate moderată. S-au recoltat probe de sânge (biochimie, HOMA-IR, citokine, steatotest) la înrolare şi după 6 şi 12 luni. La toți subiecții s-a efectuat examen CT la început şi după 12 luni pentru a evalua suprafaţa țesutului adipos visceral şi subcutanat (VAT/SAT).

Rezultate. După 12 luni, caracteristicile descriptive de la înrolare (greutate, $I M C$, circumferința abdominală) au scăzut semnificativ. Parametrii biochimici care au scăzut semnificativ au fost: $G G T(40,0 \pm 18,0$ vs $31,1 \pm 13 ; p=0,01), A L T$ $(58,5 \pm 23,5$ vs $32,7 \pm 14,8 ; p=0,001)$, colesterol $(236,4 \pm 54,8$ vs $204,8 \pm 91 ; p=$ 0,05), $L D L(160,1 \pm 47,4$ vs $125,3 \pm 40 ; p=0,05)$ şi HOMA-IR $(4,86 \pm 0,63$ vs $3 \pm$ $0,41 ; p=0,018)$. Steatotest $s$-a ameliorat semnificativ $(0,68 \pm 0,16$ vs $0,38 \pm 0,14$; $p=0,02)$. Modificările nivelurilor adipocitokinelor au fost semnificative pentru leptină $(p=0,018)$ şi adiponectină $(p=0,003)$. Factorii asociați cu regresia steatozei au fost greutatea, IMC, ALT, circumferința abdominală, GGT, HOMA, leptina, VAT şi steatotest. Regresia logistică multivariată a evidențiat următorii factori legați de ameliorarea steatozei: IMC $<25 \mathrm{~kg} / \mathrm{m}^{2}, A L T<42 \mathrm{U} / \mathrm{L}$, leptina $<$ $10,5 \mathrm{ng} / \mathrm{ml}$ şi adiponectina $>8,4 \mu \mathrm{g} / \mathrm{ml}$.

Concluzii. Persoanele supraponderale care obțin reduceri semnificative ale greutății corporale prin 12 luni de activitate fizică şi dietă hipocalorică işsi pot scădea grăsimea hepatică, VAT şi SAT. Chiar şi la cei cu scădere ponderală minimă s-au ameliorat nivelurile ALT, steatoza, adipokinele şi factorii de risc cardiovasculari.

Corresponding author: Ionel Copaci, Center of Internal Medicine, Fundeni Clinical Institute

Şos. Fundeni 258, sector 2, 022328 Bucharest, Romania

Tel: +40722300250 ; Fax: +40213119190

E-mail: ionel.copaci@gmail.com

\section{REFERENCES}

1. CHEUNG O, KAPOOR A, PURI P, SISTRUN S, LUKETIC VA, SARGEANT CC, CONTOS MJ, SHIFFMAN ML, STRAVITZ RT, STERLING RK, SANYAL AJ. The impact of fat distribution on the severity of nonalcoholic fatty liver disease and metabolic syndrome. Hepatology 2007; 46(4): 1091-1100.

2. SANYAL AJ. AGA technical review on nonalcoholic fatty liver disease. Gastroenterology 2002; 123: 1705-1725.

3. MARCHESINI G, BUGIANESI E, FORLANI G, CERRELLI F, LENZI M, MANINI R, NATALE S, VANNI E, VILLANOVA N, MELCHIONDA N, RIZZETTO M. Nonalcoholic fatty liver, steatohepatitis, and the metabolic syndrome. Hepatology 2003; 37: 917-923. 
4. FORD ES, GILES WH, DIETZ WH. Prevalence of the metabolic syndrome among US adults: findings from the third National Health and Nutrition Examination Survey. JAMA 2002; 287: 356-359.

5. JAMES WP. OVERWEIGHT AND OBESITY. IN: EZZATI A, LOPEZ HD, ROGERS HR, MURRAY CJL, eds. WHO Comparative Quantification of Health Risks. Volume 1. Geneva, Switzerland: World Health Organization, 2003: 497-596.

6. BJORNTORP P. Metabolic implications of body fat distribution. Diabetes Care 1991; 14: 1132-1143.

7. GOODPASTER BH, KRISHNASWAMI S, HARRIS TB, KATSIARAS A, KRITCHEVSKY SB, SIMONSICK EM, NEVITT M, HOLVOET P, NEWMAN AB. Obesity, regional body fat distribution, and the metabolic syndrome in older men and women. Arch Intern Med 2005; 165:777-783.

8. STANTON MC, CHEN SC, JACKSON JV, ROJAS-TRIANA A, KINSLEY D, CUI L, FINE JS, GREENFEDER S, BOBER LA, JENH CH. Inflammatory Signals shift from adipose to liver during high fat feeding and influence the development of steatohepatitis in mice. J Inflamm (Lond). 2011; 8:8.

9. PARK SH, KIM BI, KIM SH, KIM HJ, PARK DI, CHO YK, SUNG IK, SOHN CI, KIM H, KEUM DK, KIM HD, PARK JH, KANG JH, JEON WK. Body fat distribution and insulin resistance: beyond obesity in nonalcoholic fatty liver disease among overweight men. J Am Coll Nutr 2007; 26:321-326.

10. PARK BJ, KIM YJ, KIM DH, KIM W, JUNG YJ, YOON JH, KIM CY, CHO YM, KIM SH, LEE KB, JANG JJ, LEE HS. Visceral adipose tissue area is an independent risk factor for hepatic steatosis. J Gastroenterol Hepatol 2008; 23:900-907.

11. VEGA GL, ADAMS-HUET B, PESHOCK R, WILLETT D, SHAH B, GRUNDY SM. Influence of body fat content and distribution on variation in metabolic risk. J Clin Endocrinol Metab 2006; 91: 4459-4466.

12. TARGHER G, MARRA F, MARCHESINI G. Increased risk of cardio-vascular disease in non-alcoholic fatty liver disease: causal effect or epiphenomenon? Diabetologia 2008; 51: 1947-1953.

13. MISRA VL, KHASHAB M, CHALASANI N. Nonalcoholic fatty liver disease and cardiovascular risk. Curr Gastroenterol Rep 2009; 11:50-55.

14. BIDDINGER SB, HERNANDEZ-ONO A, RASK-MADSEN C, HAAS JT, ALEMAN JO, SUZUKI R, SCAPA EF, AGARWAL C, CAREY MC, STEPHANOPOULOS G, COHEN DE, KING GL, GINSBERG HN, KAHN CR. Hepatic insulin resistance is sufficient to produce dyslipidemia and susceptibility to atherosclerosis. Cell Metab 2008; 7:125-134.

15. IRWIN ML, AINSWORTH BE, MAYER-DAVIS EJ, ADDY CL, PATE RR, DURSTINE JL. Physical activity and the metabolic syndrome in a tri-ethnic sample of women. Obes Res 2002; 10:1030.

16. KATZMARZYK PT, CHURCH TS, BLAIR SN. Cardiorespiratory fitness attenuates the effects of the metabolic syndrome on all-cause and cardiovascular disease mortality in men. Arch Intern Med 2004; 164:1092-1097.

17. CHURCH TS, KUK JL, ROSS R, PRIEST EL, BILTOFT E, BLAIR SN. Association of cardiorespiratory fitness, body mass index, and waist circumference to nonalcoholic fatty liver disease. Gastroenterology 2006; 130:2023-2030.

18. PERSEGHin G, LATTUAdA G, DE COBElli F, RAGOGNA F, NTALi G, ESPOSITO A, BELlONI E, CANU T, TERRUZZI I, SCIFO P, DEL MASCHIO A, LUZI L. Habitual physical activity is associated with intrahepatic fat content in humans. Diabetes Care 2007; 30:683-688.

19. JOHNSON NA, GEORGE J. Fitness versus fatness: moving beyond weight loss in nonalcoholic fatty liver disease. Hepatology 2010; 52(1):370-381.

20. KANTARTZIS K, THAMER C, PETER A, MACHANN J, SCHICK F, SCHRAML C, KÖNIGSRAINER A, KÖNIGSRAINER I, KRÖBER S, NIESS A, FRITSCHE A, HÄRING HU, STEFAN N. High cardiorespiratory fitness is an independent predictor of the reduction in liver fat during a lifestyle intervention in non-alcoholic fatty liver disease. Gut 2009; 58:1281-1288.

21. NEUSCHWANDER-TETRI BA, CALDWELL SH. Nonalcoholic steatohepatitis: summary of an AASLD Single Topic Conference. Hepatology 2003; 37:1202-1219.

22. ZELBER-SAGI S, NITZAN-KALUSKI D, GOLDSMITH R, WEBB M, ZVIBEL I, GOLDINER I, BLENDIS L, HALPERN Z, OREN R. Role of leisure-time physical activity in nonalcoholic fatty liver disease: a population-based study. Hepatology 2008; 48(6): 1791-1798.

23. WILLIAMS MA, HASKELL WL, ADES PA, AMSTERDAM EA, BITTNER V, FRANKLIN BA, GULANICK M, LAING ST, STEWART KJ; American Heart Association Council on Clinical Cardiology; American Heart Association Council on Nutrition, Physical Activity, and Metabolism. Resistance exercise in individuals with and without cardiovascular disease. 2007 update: a scientific statement from the American Heart Association Council on Clinical Cardiology and Council on Nutrition, Physical Activity, and Metabolism. Circulation 2007; 116:572-584.

24. LAWLOR DA, SATTAR N, SMITH GD, EBRAHIM S. The associations of physical activity and adiposity with alanin aminotransferase and gamma glutamyltransferase. Am J Epidemiol 2005; 161:1081-1088.

25. KHAOSHBATEN M, GHOLAMI N, SOKHTEHZARI S, MONAZAMI AH, NEJAD MR. The effect of an aerobic exercise on serum level of liver enzymes and liver echogenicity in patients with non-alcoholic fatty liver disease. Gastroenterol Hepatol Bed Bench 2013; 6 (Suppl.1):S112-S116).

26. KEATING SE, HACKETT DA, GEORGE J, JOHNSON NA. Exercise and non-alcoholic fatty liver disease: a systematic review and meta-analysis. J Hepatol 2012; 57: 157-166.

27. RECTOR RS, THYFAULT JP, MORRIS RT, LAYE MJ, BORENGASSER SJ, BOOTH FW, IBDAH JA. Daily exercise increases hepatic fatty acid oxidation and prevents steatosis in Otsuka Long-Evans Tokushima Fatty rats. Am J Physiol Gastrointest Liver Physiol 2008; 294: G619-G626.

28. ROCHA R, COTRIM HP, CARVALHO FM, SIQUEIRA AC, BRAGA H, FREITAS LA. Body mass index and waist circumference in nonalcoholic fatty liver disease. J Hum Nutr Diet 2005; 18: 365-370.

29. DESPRES JP, LEMIEUX I, BERGENON J, PIBAROT P, MATHIEU P, LAROSE E, RODÉS-CABAU J, BERTRAND OF, POIRIER P. Abdominal obesity and the metabolic syndrome: contribution to global cardiometabolic risk. Arterioscler Tromb Vasc Biol 2008; 28: 1039-1049. 
30. MATHURIN P, HOLLEBECQUE A, ARNALSTEEN L, BUOB D, LETEURTRE E, CAIAZZO R, PIGEYRE M, VERKINDT H, DHARANCY S, LOUVET A, ROMON M, PATTOU F. Prospective study of the long-term effects of bariatric surgery on liver injury in patients without advanced disease. Gastroenterology 2009; 137: 532-540.

31. SIRI-TARINO PW, SUN Q, HU FB, KRAUSS RM. Saturated fatty acids and risk of coronary heart disease: modulation by replacement nutrients. Curr Atheroscler Rep 2010; 12: 384-390.

32. DE LUIS DA, ALLER R, IZAOLA O, GONZALEZ SAGRADO M, CONDE R. Effect of two different hypocaloric diets in transaminases and insulin resistance in nonalcoholic fatty liver disease and obese patients. Nutr Hosp 2010; 25: 730-735.

33. PROMRAT K, KLEINER DE, NIEMEIER HM, JACKVONY E, KEARNS M, WANDS JR, FAVA JL, WING RR. Randomized controlled trial testing the effects of weight loss on nonalcoholic steatohepatitis. Hepatology 2010, 51 (1): 121-129.

34. CHEN SM, LIU CY, LI SR, HUANG HT, TSAI CY, JOU HJ. Effects of therapeutic lifestyle program on ultrasound-diagnosed nonalcoholic fatty liver disease. J Clin Med Assoc 2008; 71:551-558.

35. CHITTURI S, FARRELL G, FROST L, KRIKETOS A, LIN R, FUNG C, LIDDLE C, SAMARASINGHE D, GEORGE J. Serum leptin in NASH correlates with hepatic steatosis but not fibrosis: a manifestation of lipotoxicity? Hepatology 2002; 36 : 403-409.

36. BAJAJ M, SURAAMORNKUL S, HANDIES LJ, PRATIPANAWATR T, DEFRONZO RA. Plasma resistin concentration, hepatic fat content and hepatic and peripheral insulin resistance in pioglitazone-treated type II diabetic patients. Int $\mathrm{J}$ Obes Relat Metab Disord 2004; 28: 783-789.

37. DYCK DJ. Leptin sensitivity in skeletal muscle is modulated by diet and exercise. Exerc Sport Sci Rev 2005; 33: 189-194.

38. GOMEZ-MERINO D, CHENNAOUI M, DROGOU C, BONNEAU D, GUEZENNEC CY. Decrease in serum leptin after prolonged physical activity in men. Med Sci Sports Exerc 2002; 34: 1594-1599.

39. FISHMAN S, MUZUMDAR RH, ATZMON G, MA X, YANG X, EINSTEIN FH, BARZILAI N. Resistance to leptin action is the major determinant of hepatic triglyceride accumulation in vivo. FASEB J 2007; 21: 53-60.

40. THONG FS, HUDSON R, ROSS R, JANSSEN I, GRAHAM TE. Plasma leptin in moderately obese men: independent effects of weight loss and aerobic exercise. Am J Physiol Endocrinol Metab 2000; 279(2): E307-13.

41. CHATTERJEE S, GANINI D, TOKAR EJ, KUMAR A, DAS S, CORBETT J, KADIISKA MB, WAALKES MP, DIEHL AM, MASON RP. Leptin is key to peroxynitrite-mediated oxidative stress and Kupffer cell activation in experimental non-alcoholic steatohepatitis. J Hepatol 2013; 58:778-784.

42. KAMMOUN HL, CHABANON H, HAINAULT I, LUQUET S, MAGNAN C, KOIKE T, FERRÉ P, FOUFELLE F. GRP78 expression inhibits insulin and ER stress - induced SREBP-1c activation and reduces hepatic steatosis in mice. J Clin Invest 2009; 119: 1201-1215.

43. TARGHER G, BERTOLINI L, ZENARI L. Hypoadiponectinemia is closely associated with nonalcoholic hepatic steatosis in obese subjects. Diabetes Care 2004; 27: 2085-2086.

44. BRAY GA, JABLONSKI KA, FUJIMOTO WY, BARRETT-CONNOR E, HAFFNER S, HANSON RL, HILL JO, HUBBARD V, KRISKA A, STAMM E, PI-SUNYER FX. Diabetes Prevention Program Research Group. Relation of central adiposity and body mass index to the development of diabetes in the Diabetes Prevention Program. Am J Clin Nutr 2008; 87:1212-8.

45. LAZO M, SOLGA SF, HORSKA A, BONEKAMP S, DIEHL AM, BRANCATI FL, WAGENKNECHT LE, PI-SUNYER FX, KAHN SE, CLARK JM. Fatty Liver Subgroup of the Look AHEAD Research Group. Effect of a 12-month intensive lifestyle intervention on hepatic steatosis in adults with type 2 diabetes. Diabetes Care 2010; 33: 2156-2163.

46. HWANG JH, STEIN DT, BARZILAI N, CUI MH, TONELLI J, KISHORE P, HAWKINS M. Increased intrahepatic triglyceride is associated with peripheral insulin resistance: in vivo MR imaging and spectroscopy studies. Am J Physiol Endocrinol Metab 2007; 293: E1663-E1669.

47. KORENBLAT KM, FABBRINI E, MOHAMMED BS, KLEIN S. Liver, muscle, and adipose tissue insulin action is directly related to intrahepatic triglyceride content in obese subjects. Gastroenterology 2008; 134: 1369-1375.

48. SHEN W, WANG Z, PUNYANITA M, LEI J, SINAV A, KRAL JG, IMIELINSKA C, ROSS R, HEYMSFIELD SB. Adipose tissue quantification by imaging methods: a proposed classification. Obes Res 2003; 11:5-16.

49. ST GEORGE A, BAUMAN A, JOHNSTON A, FARRELL G, CHEY T, GEORGE J. Independent effects of physical activity in patients with nonalcoholic fatty liver disease. Hepatology 2009; 50: 68-76.

Received February 15, 2015 